\title{
THE IMPACT OF PQ4R STRATEGY USE ON EFL STUDENTS' READING COMPREHENSION
}

\author{
Nurul Lailatul Khusniyah \\ UIN Mataram,nurullaila@uinmataram.ac.id
}

\begin{abstract}
This study aimed at examining the effect of PQ4R strategy use on EFL students' reading comprehension. This action research involved 34 students of English departments of UIN Mataram (Mataram State Islamic University), in which pre- and post-tests were applied to collect and measure the students' reading comprehension respectively before and after the treatment. The data garnered were computed using Independent sample t-test formula. The statistical evidence showed that the use of PQ4R significantly improved students' reading comprehension given the statistical evidence (5.38) > t-table (1.99).
\end{abstract}

Keywords: English Learning, PQ4R Strategy, Reading Comprehension.

\section{INTRODUCTION}

In human life, language plays a very fundamental role, humans can live because they have and master the language. It also helps to carry out interaction and communication well. With language, humans can fulfill various physical needs, work, and live as social beings, and fulfill spiritual needs. Hence, it affects the formation of social and cultural life of the community (Sugono, 2014), particularly English reading comprehension skill. Jane, Cain and Elbro (2015) argue that reading comprehension is important, not only for understanding text, but also for broader learning, success in education, and employment. It is even important for our social lives because of email, text, and social networking sites. It is a complex task, which requires the orchestration of many different cognitive skills and abilities. It becomes the foundation for the Study Program to determine the learning outcomes of the four 
reading courses as one of the leading courses. Reading skills must be able to be used by students in everyday life. In addition, the learning process of other subjects has also used references or books in English, so the students need good reading skills to understand the contents. Hence, the learning process of reading takes a long process to reach the level of reading comprehension to the critical level. The students must have an understanding of the context to interpret the meaning embedded in the contents of the reading. However, this condition has not been achieved, especially in the reading course.

With reference to the objectives, the main objectives of reading comprehension are (1) the students would be able to develop competence in interpreting various types of texts and controlling self-affinity both in fictional texts or others at a higher level; and (2) the students would be able to use appropriate reading strategies to understand information implicitly in text, recognize discourse markers, identify text structures, develop and analyze various types of texts. The real conditions of observations and interviews conducted in English Language Education Study Program Mataram UIN in the 2015/2016 years showed that the learning outcomes of the reading class had not shown the expected learning outcomes.

There were some challenges the students encountered for learning reading comprehension skills. First, the students still had difficulty interpreting the meaning of the text in the reading caused by a) literal or contextual meaning of words and sentences; b) synthesizing words, phrases or sentences into the exact meanings desired by the author's context; c) the difficulty in identifying the subject matter in the text; d) the difficulty in taking the conclusions of the text. Second, the reading source was less varied; and third, there were many students who still lacked reading proficiency.

The learning strategies that had been used so far did not meet the needs of the reading comprehension learning process. Therefore, the PQ4R strategy was applied as it offers a new learning model that is able to encourage the optimal use of cognitive skills. It provides opportunities for students to learn systematically, effectively and efficiently. This strategy requires students to repeat reading material from the stage of reviewing the 
Khusniyah, N. L., The Impact of PQ4R...

reading or (preview), asking (question), reading (reading), reflection on information that has been obtained, telling or rewriting (recite), and review. This strategy is thought to be able to realize the ideal conditions to be achieved in the learning process of understanding reading.

For this reason, this study aimed at examining the effect of PQ4R strategy use on EFL students' reading comprehension. The following research question guiding the whole part of this research was did the use of PQ4R significantly improved the students reading comprehension?

\section{LITERATURE REVIEW}

\section{Reading Comprehension}

Harris and Hodges as cited in Brassell and Rasinski stated that reading comprehension is a process of building meaning through reciprocal written communication, a holistic exchange of ideas between interpreters and messages (2008). For most lecturers, reading comprehension is what they say about reading skills. That is the end of the reading process and what happens when all components interact successfully. It can be said that reading comprehension is the process of managing all the information, feelings and thoughts that are desired to be transferred because they have no cause for misunderstanding and without leaving clarity (Khabiri \& Pakzad, 2012).

Baker revealed that reading and listening are processes that need each other not only to understand literal meanings, but also to understand their ideas. This is in line with Tierney who stated that reading learning is not only learning to recognize words; but also learning to make the meaning of the text more logical because reading is the interaction of four things, namely the reader, the text, fluency in reading and reading strategies. Similar account has been evidenced in the research of Batul and Masoud who investigated the effect of CALLA, Cognitive Academic Language Learning Approach, on the students' reading comprehension. The results showed a significant correlation between the use of the instructional approach and students' reading comprehension 
(2015). The process of learning is not only for understanding, but also for improving reading skills. The finding of this research indicates that the use of appropriate instructional strategy could effectively improve students' reading comprehension, for example CALLA, an instructional model for second and foreign language learners which is based on the cognitive theory and research. It integrates instruction in priority topics from the content curriculum, development of the language skills needed for learning in school, and explicit instruction in using learning strategies for academic tasks. The goals of CALLA are for students to learn essential academic content and language and to become independent and self-regulated learners through their increasing command over a variety of strategies for learning in school (Chamot \& Robbins, 2005). Wooley (2011) opines that reading comprehension is the process of making meaning from the text. The goal is the overall understanding of what is described in the text rather than looking for meaning from the separation of words or sentences.

It can be explained that the learning process of reading comprehension in this action research consists of three elements. The first element is the text, which consists of various types of reading with the construction of the message to be conveyed. Second, readers who are influenced by factors that originate from students. These factors influence the students in meaning construction. Third, the activity that can be done individually or in groups. Reading comprehension activities can be done in schools, homes or workplaces. These three elements are also influenced by socio-cultural conditions and contexts.

\section{PQ4R Strategy}

The strategy of PQ4R is considered one of the metacognition strategies. It is known as a strategy that deals with the education of learning in that it helps learners to comprehend, memorize, and retain the included reading topics in order to access to the real learning; so students shall be aware of the contents of the texts; which helps them transfer their learning to other learning situations. Thus, students will be able to self-learn following the basic steps of this strategy, namely: Preview (P), Question (Q), 
Reading (R), Reflect (R), Recite (R), Review (R) (Sudarman, 2009 as cited in Hassan \& Aljaz, 2018). The following table 1 presents the differences from each step in the SQ4R strategy compared to SQ3R and PQ4R.

Tabel 1. The differences of SQ3R, SQ4R, dan PQ4R Strategy

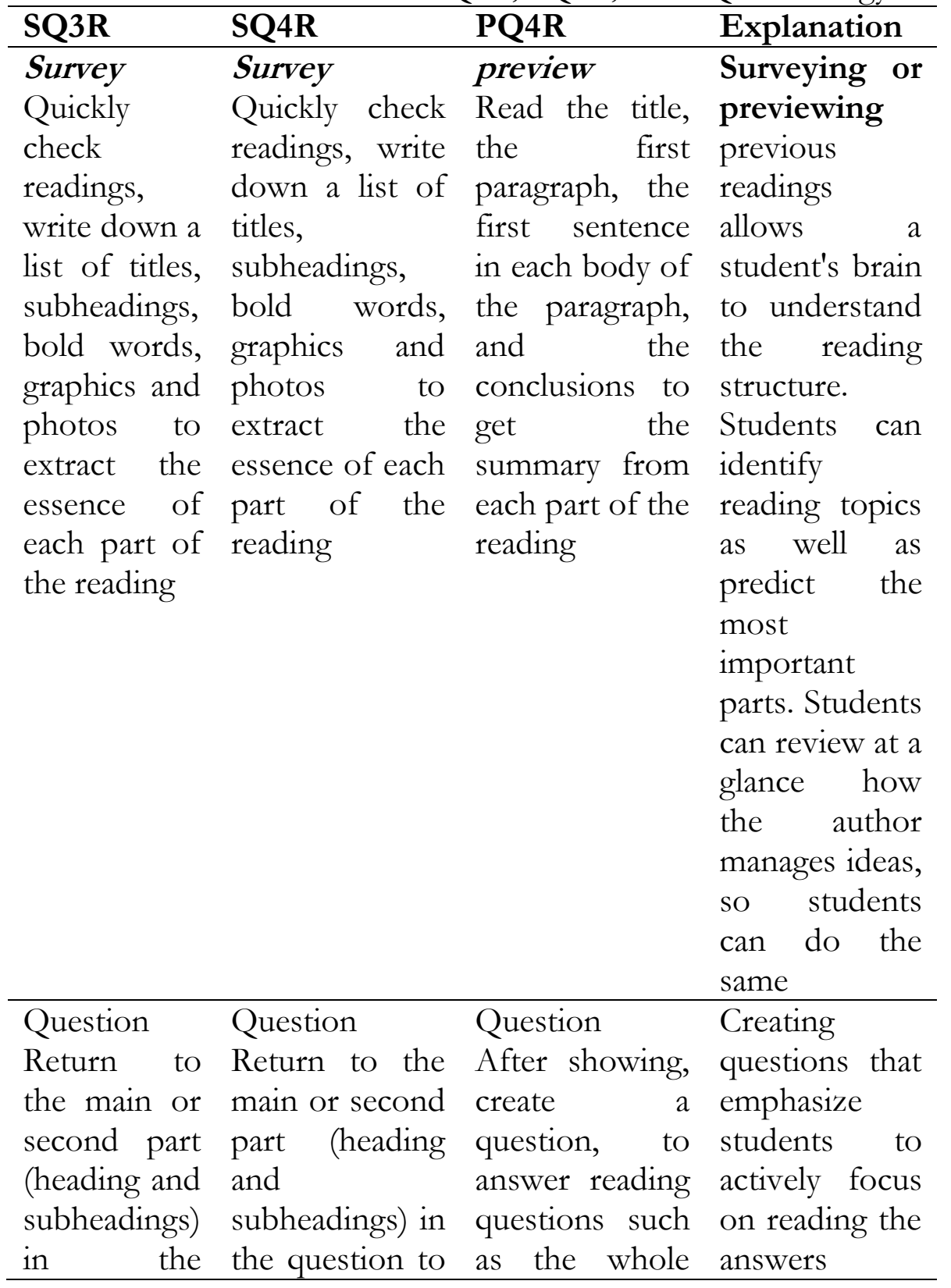




\begin{tabular}{|c|c|c|c|}
\hline $\begin{array}{l}\text { question to } \\
\text { focus on the } \\
\text { reading and } \\
\text { concentrate } \\
\text { on the } \\
\text { answer to } \\
\text { the question } \\
\text { (who, what, } \\
\text { where, } \\
\text { when, why, } \\
\text { how) }\end{array}$ & $\begin{array}{l}\text { focus on the } \\
\text { reading and } \\
\text { concentrate on } \\
\text { the answer to } \\
\text { the question } \\
\text { (who, what, } \\
\text { where, when, } \\
\text { why, how) }\end{array}$ & $\begin{array}{l}\text { and or for each } \\
\text { paragraph or } \\
\text { section. Then } \\
\text { return to the } \\
\text { subheadings in } \\
\text { the question, or } \\
\text { determine the } \\
\text { topic and then } \\
\text { use it to } \\
\text { arrange } \\
\text { questions so } \\
\text { that the focus } \\
\text { is on reading } \\
\text { (who, what, } \\
\text { where, when, } \\
\text { why, how) }\end{array}$ & \\
\hline $\begin{array}{l}\text { Read } \\
\text { Read to find } \\
\text { answers that } \\
\text { have been } \\
\text { determined }\end{array}$ & $\begin{array}{l}\text { Read } \\
\text { Read to find } \\
\text { answers that } \\
\text { have been } \\
\text { determined }\end{array}$ & $\begin{array}{l}\text { Read } \\
\text { Read to find } \\
\text { answers that } \\
\text { have been } \\
\text { determined }\end{array}$ & $\begin{array}{l}\text { Focus on } \\
\text { reading to find } \\
\text { answers, } \\
\text { students } \\
\text { minimize the } \\
\text { possibility of } \\
\text { missing things } \\
\text { and increase } \\
\text { the possibility } \\
\text { of } \\
\text { understanding } \\
\text { what students } \\
\text { are reading }\end{array}$ \\
\hline $\begin{array}{l}\text { Recite } \\
\text { Repeat hard, } \\
\text { what is in } \\
\text { the mind, or } \\
\text { write } \\
\text { answers } \\
\text { questions, as } \\
\text { well as mark } \\
\text { what has }\end{array}$ & $\begin{array}{l}\text { Recite } \\
\text { Repeat hard, } \\
\text { what is in the } \\
\text { mind, or write } \\
\text { answers } \\
\text { questions, as } \\
\text { well as mark } \\
\text { what has been } \\
\text { determined }\end{array}$ & $\begin{array}{l}\text { Reflect } \\
\text { Linking what } \\
\text { students have } \\
\text { read and } \\
\text { answered the } \\
\text { questions that } \\
\text { have been } \\
\text { determined: }\end{array}$ & $\begin{array}{l}\text { Telling is the } \\
\text { process of } \\
\text { repeating } \\
\text { information } \\
\text { so that it can } \\
\text { begin the } \\
\text { process of } \\
\text { encoding and } \\
\text { storing }\end{array}$ \\
\hline
\end{tabular}


Khusniyah, N. L., The Impact of PQ4R...

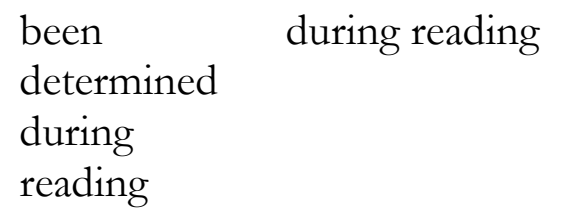

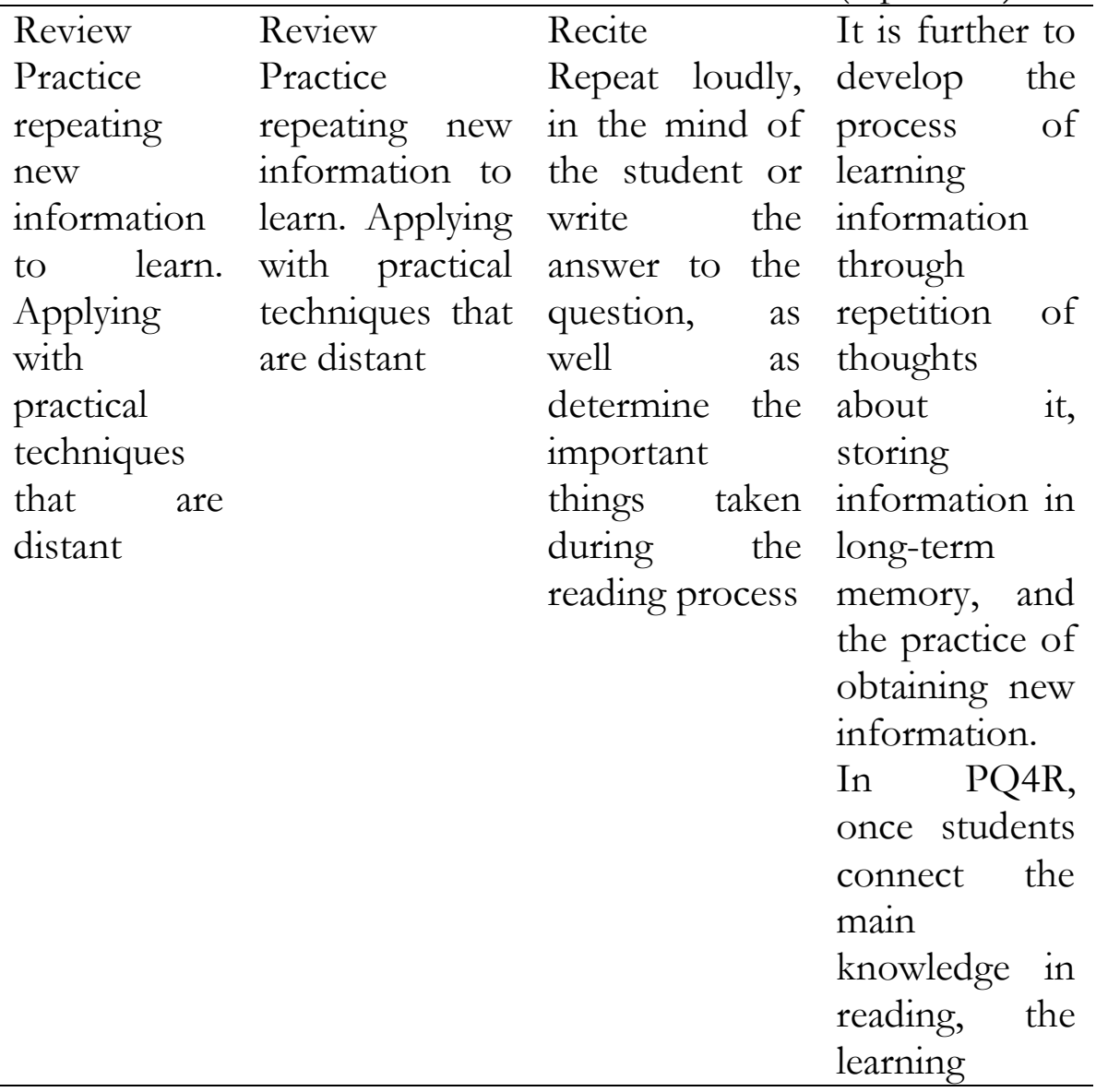




\begin{tabular}{|c|c|c|}
\hline & & process begins \\
\hline \multirow{22}{*}{$\begin{array}{l}\text { Reflect } \\
\text { Thinking about } \\
\text { information, } \\
\text { critically } \\
\text { evaluating it, } \\
\text { and connecting } \\
\text { it to key } \\
\text { knowledge and } \\
\text { other } \\
\text { information } \\
\text { learned to link } \\
\text { each other }\end{array}$} & \multirow{22}{*}{$\begin{array}{l}\text { Review } \\
\text { Repeatedly } \\
\text { review material } \\
\text { through asking } \\
\text { yourself and } \\
\text { saying, } \\
\text { thinking, or } \\
\text { writing } \\
\text { answers. Only } \\
\text { refers } \\
\text { student records } \\
\text { if students have } \\
\text { them too }\end{array}$} & SQ4R ends \\
\hline & & with analysis, \\
\hline & & synthesis, and \\
\hline & & material \\
\hline & & evaluation \\
\hline & & (critical \\
\hline & & critical \\
\hline & & thinking at the \\
\hline & & level of \\
\hline & & understanding \\
\hline & & in college) \\
\hline & & PQ4R ends \\
\hline & & with the need \\
\hline & & for repetition \\
\hline & & for the \\
\hline & & process \\
\hline & & receiving new \\
\hline & & information \\
\hline & & into long-term \\
\hline & & memory and \\
\hline & & finding $\quad$ it \\
\hline & & accurately \\
\hline
\end{tabular}

\section{Method}

This study was grounded in the exploratory action research design based on Elliot model as cited in (Valsa, 2005, p.5). Action will be declared successful if the students' activity in the learning process is to achieve good category marked, which at least reaches an average score of 75 . The 34 students of English Department at State Islamic University Mataram in 2017-2018 academic years were involved. The data collection procedure involved observations, tests, journals, and interview. To determine the reliability of data, the researchers used Lincoln and Guba as cited in Creswell (2007, p.202). terms, such as credibility, transferability, dependability, and conformability. 
Khusniyah, N. L., The Impact of PQ4R...

\section{Findings and Discussions}

The empirical evidence showed that PQ4R strategy appplied in learning reading was found to significantly improve students' reading comprehension. The following table 1 portrayed such a finding, which documented the pre- and post-test results of the students' reading comprehension before and after the use of PQ4R strategy:

Table 1. The difference between the pre-test and post-test score of experimental and control group

\begin{tabular}{lll}
\hline & pretest & posttest \\
\hline Mean & 68.17647059 & 81.44117647 \\
\hline Df & 66 & \\
\hline $\mathrm{t}$ Stat & -10.08428461 & \\
\hline $\mathrm{P}(\mathrm{T}<=\mathrm{t})$ two-tail & 5.3833 & \\
\hline
\end{tabular}

From the table above, the result shows that $\mathrm{t}-\mathrm{Stat}(-10.08)<$ t-table (2.001), which means $\mathrm{Ho}_{\mathrm{i}}$ is rejected and $\mathrm{H}_{1}$ is accepted. Besides that, if it sees $\mathrm{P}(\mathrm{T}-\mathrm{t})$ two-tail (5.38) $>\mathrm{t}$-table (t Critical twotail $)=1.99$. It can conclude that learning process using PQ4R strategy on reading comprehension learning has improved. Thus, it can be concluded that the post-test and pre-test is significantly different. The mind mapping technique is effective to use.

As found in the previous research regarding the significance of PQ4R strategy, Kedsupap (2018) has found that Achievement reading comprehension of Prathomsuksa 5 students at Prachauppathum School after learning by using PQ4R technique was higher than before learning at the statistical significance level of .05. The students' opinions towards PQ4R technique were at a high level. Eka, As1, and Yuliana (2018) prove that PQ4R strategy has successfully increased the students' reading comprehension. It can be seen from the result of pre-test and post-test. The students' mean score in post-test (83.59) is higher than in the pretest (62.50). A successful teaching reading depends on how the teacher the lesson. Therefore, for the sake of improvements of students' reading comprehension, English teachers are suggested to apply PQ4R strategy in teaching reading because this technique is appropriate to improve students' reading comprehension to comprehend the text and find out the information of the text. The 
same research from Shoaib, et.al., (2016) that has recommended the English teacher should use PQ4R strategy for enhancing students' attention which will help on their achievement in English subject. The results confirmed the views of Pehofer and Roy (2003),(Dunn, 2006) and Reddy and Ramar (2006) who considered involvement, concentration and short time activities as essential for increasing attention and effective learning.

The PQ4R strategy has advantages that can help students understand the contents of the reading, among others; 1) through preview activities at the learning stage can arouse students' curiosity about the material being studied so that it can motivate student learning; 2) students have a great opportunity to ask questions and try to find answers to these questions by themselves through reading activities, so that this encourages critical thinking patterns, active learning and meaningful learning; and 3) through activities that explore students' abilities, reading comprehension material that has been learned can be inherent for a long period of time. This can be seen from the successful implementation of the PQ4R strategy towards learning foreign languages. While the weakness faced by lecturers in implementing PQ4R is that this strategy is too systematic, so it requires complicated preparation. Lecturers must be able to design learning with all the preparations needed. Thus, the lecturer must strive to prepare all learning needs.

The strengths and weaknesses of this strategy require the lecturer to work harder to direct the student's independent learning process such as completing learning tasks and applying them to conditions other than classroom learning. When lecturers implement this strategy, they are required to be able to design classroom learning that directs the stages of using the SQ4R strategy. Activities carried out are not only collaborative, but assignments must be balanced. Students who have higher abilities can become guides for students who have low abilities. Thus, it was concluded that the selection of the SQ4R strategy as a solution to the problems faced during the learning process of reading comprehension was better than the task-based learning method that had been applied before. Students can easily and systematically learn to understand reading 
Khusniyah, N. L., The Impact of PQ4R...

\section{Conclusion and Implications}

PQ4R is one of the appropriate learning strategies for increasing students' reading skill. This strategy allows the learners to comprehend and memorize during the reading process. Through PQ4R strategy, students can develop their thinking to develop their comprehension and also makes students creative in finding the ideas. The implementation of PQ4R in UIN Mataram can be concluded that it has influenced in teaching for improving reading skill. It gives students more opportunity to express their ideas, at the same time making them feel enjoy in the class.

The benefit of using PQ4R strategy in reading skill for students at UIN Mataram can help them to practice their confidence in front of their classmate. It also provides teachers with insight into their students' thought process regarding a specific topic. The disadvantage in PQ4R strategy is that students and teacher need more time to practice their skill in implementing of procedure. The research recommends that the teacher be able to adopt PQ4R strategy as an effective method of English teaching and learning. The teacher can be combined with the other media of learning.

\section{REFERENCES}

Hassan, A. R., \& Aljaz, A. A. (2018). The effectiveness of using PQ4R strategy in teaching reading comprehension in Arabic language subject among ninth grade students' achievement in Jordan. World Journal of Educational Research 5(2), 159-171.

Brassell, D., \& Rasinski, T. (2008). Comprehension That Works Taking Students Beyond Ordinary Understanding to Deep Comprehension. CA: Shell Education

Khabiri, M., \& M. Pakzad. (2012). The effect of teaching critical reading strategies on EFL learners' vocabulary retention. Journal Teaching Language Skills, 4(1), 73-106.

Kedsupap, C. (2018). A Development of Reading Comprehension Achievement of Prathomsuksa 5 Students Using PQ4R Technique. Journal of MCU Buddhapanya Review 3(2). Retrieved from https:/ / tci-thaijo.org/index.php/jmbr/article/view/135864 
Eka, M. D., As1, I., \& Yuliana. (2018). The effect of using PQ4R (preview, question, read, reflect, recite, review) strategy on EFL students' reading comprehension achievement. Research in English and Education (READ), 3(1), 17-24.

Batul, N., \& Masoud, M. S. (2015). Effect of Metacognitive Strategy Instruction on the Reading Comprehension of English Language Learners Through Cognitive Academic Language Learning Approach (CALLA). International Journal of Languages' Education and Teaching 3(2), 133-164.

Oakhill, J., Cain, K., \& Elbro, C. (2015). Understanding and teaching reading comprehension: $A$ bandbook. London \& New York: Routledge.

Sugono, Dendy. (2014). Peran dan kekuatan bahasa indonesia dalam industri kreatif kebahasaan. Jakarta: Badan Pengembangan dan Pembinaan Bahasa Kementerian Pendidikan dan Kebudayaan, 2014

Sudarman. (2009). Peningkatan pemahaman dan daysa ingat siswa melalui strategi preview, question, read, reflect, recite, dan review pq4r. Journal Pendidikan inovatif (JPT), 4(2), 67-72.

Wooley, Gary. (2011). Reading comprehension assisting cbildren with learning difficulties. London \& New York: Springer.

Valsa, K. (2005). Action research for improving practice: A practical guide. London:Paul Chapman Publishing 